\title{
TINDAK PIDANA PEMALSUAN DALAM PENDAFTARAN HAK ATAS TANAH DAN IMPLIKASI HUKUM PENERBITAN SERTIFIKAT YANG TIDAK PROSEDURAL
}

\author{
Fachrul Marasabessy ${ }^{1}$ \\ fachrulmarasabessy@ymail.com
}

\begin{abstract}
"The issue of criminal forgery in registering land rights is an unlawful act that can cause material or immaterial losses to the actual landowner and will also have implications for non-procedural certificates issued by the National Land Agency (BPN) office, therefore professionalism in carrying out public services and administrative tasks must be carried out in accordance with the laws and regulations to be able to provide legal certainty, justice and benefit to all parties in accordance with the objectives of the law. Criminal law enforcement must still be carried out if there are indications of criminal elements involving the applicant for land rights with an officer in the land office so that public trust in the land institution can be maintained".
\end{abstract}

\section{Pendahuluan}

Negara Indonesia adalah Negara Hukum menurut UUD 1945 Pasal 1 ayat (3). Negara sebagai konsep kekuasaan memiliki sejumlah tujuan hakiki sebagai pengemban tujuan dari seluruh warga negaranya. ${ }^{2}$ Konsep Negara Hukum 'rechtsstaat' yang dipelopori oleh Julius Stahl, itu mencakup empat elemen penting, yaitu : Perlindungan hak asasi manusia, Pembagian kekuasaan, Pemerintahan berdasarkan undang-undang, Peradilan tata usaha Negara. ${ }^{3}$ Hukum dibuat untuk menciptakan ketertiban dan kesejahteraan melalui hukum yang adil, yakni pengaturan kepentingan-kepentingan yang saling bertentangan dengan seimbang sehingga setiap orang memperoleh sebanyak mungkin apa yang menjadi bagiannya. Tujuan hukum menurut Gustav Radbruch, terdiri dari tiga ide dasar hukum atau tiga nilai dasar hukum yaitu: Keadilan, Kemanfaatan dan Kepastian hukum. ${ }^{4}$ Pasal 33 ayat 3 UUD 1945 bumi dan air dan kekayaan alam yang terkandung didalamnya dikuasai oleh

\footnotetext{
${ }^{1}$ Dosen Tetap Prodi Hukum Ekonomi Syariah STAI Asy-Syukriyyah

${ }^{2}$ Supriadi, 2010 : 58, Hukum Agraria. Cetakan keempat.

${ }^{3}$ Jimly Asshiddiqie : Gagasan Negara Hukum Indonesia.

${ }^{4}$ Amiruddin Sale 2007 Hukum Pengadaan Tanah Untuk Kepentingan Umum. Cetakan Pertama, Yogyakarta.
} 


\section{Jurnal Asy-Syukriyyah}

negara dan dipergunakan sebesar-besar kemakmuran rakyat, maka dalam penguasaan tanah oleh negara Indonesia untuk sebesar-besar kemakmuran rakyat

Tanah sangat erat hubungannya dengan kehidupan manusia sehari-hari, bahkan dapat dikatakan setiap saat manusia berhubungan dengan tanah. ${ }^{5}$ Setiap orang memerlukan tanah tidak hanya pada masa hidupnya, tetapi sudah meninggalpun masih tetap berhubungan dengan tanah. Oleh karena itu sering sekali terjadi sengketa diantara sesamanya. untuk itulah diperlukan kaedah-kaedah yang mengatur hubungan manusia dengan tanah. Tanah merupakan karunia tuhan yang maha esa, atas dasar hak menguasai dari negara maka menjadi kewajiban bagi pemerintah melaksanakan pendaftaran tanah di seluruh wilayah Republik Indonesia menurut Undang - Undang Pokok Agraria (selanjutnya disingkat dengan UUPA) yang individualistik komunalistik religius, selain bertujuan melindungi tanah juga mengatur hubungan hukum atas tanah melalui penyerahan sertifikat sebagai tanda bukti hak atas tanah bagi pemegangnya. ${ }^{6}$

Salah satu fenomena yang terjadi dalam permasalahan dibidang tanah adalah masalah tindak pidana pemalsuan dalam pendaftaran hak atas tanah, dari beberapa kasus mengenai sertifikat hak atas tanah terungkap bahwasanya terdapat penerbitan sertifikat oleh Kantor Pertanahan yang ternyata surat-surat bukti sebagai alas/dasar penerbitan sertifikat tidak benar atau dipalsukan. Penerbitan suatu sertifikat merupakan suatu proses yang memerlukan peran serta dari beberapa instansi lain yang terkait dalam menerbitkan surat-surat keterangan yang diperlukan sebagai alas hak, misalnya surat keterangan Kepala Desa atau Kelurahan, Keterangan Warisan, segel jual beli dan sebagainya. Surat-surat keterangan tersebut tidak luput pula dari pemalsuan, kadaluwarsa, bahkan ada kalanya tidak benar atau fiktif.

Tindak pidana pemalsuan menurut pasal 263 KUHP adalah Barang siapa membuat surat palsu atau memalsukan surat yang dapat menimbulkan sesuatu hak, perikatan atau pembebasan hutang, atau yang diperuntukkan sebagai bukti daripada sesuatu hal dengan maksud untuk memakai atau menyuruh orang lain memakai surat tersebut seolah-olah isinya benar dan tidak dipalsu, diancam jika pemakaian tersebut dapat

\footnotetext{
${ }^{5}$ Mudjiono, Politik dan Hukum Agraria, Cet. Pertama, Liberty, Yogyakarta, 1997, hal. 19.

${ }^{6}$ S. Chandra, Sertifikat Kepemilikan Hak Atas Tanah, (Jakarta: Raja Grafindo Persada, 2005)

hal.3.
} 
menimbulkan kerugian, karena pemalsuan surat, dengan pidana penjara paling lama enam tahun.

Kejahatan pertanahan dalam KUHP adalah perbuatan-perbuatan yang dilarang oleh peraturan perundang-undangan yang disertai sanksi pidana bagi yang melakukannya.3 Pendapat para sarjana hukum membedakan kejahatan pertanahan dari segi waktunya menjadi tiga bagian yaitu: 1) praperolehan; 2) menguasai tanpa hak; 3) mengakui tanpa hak. Apabila dirinci, kejahatan pertanahan dalam KUHP terdapat pada Buku II dan Buku III diantaranya dibedakan dari segi waktunya: ${ }^{7}$

Berdasarkan uraian dan permasalahan diatas maka perlu dilakukan analisis tentang tindak pidana pemalsuan dalam pendaftaran hak atas tanah yang mengakibatkan penerbitan sertifikat hak atas tanah dengan data-data palsu dan menganalisis tentang implikasi hukum penerbitan sertifikat yang tidak prosedural serta proses penegakan hukum bagi tindak pidana pemalsuan.

Berdasarkan hal-hal yang telah diuraikan dalam latar belakang diatas, untuk membatasinya perlu dirumuskan permasalahan yang hendak diteliti yaitu antara lain:

1) Faktor-faktor penyebab tindak pidana pemalsuan dalam pendaftaran hak atas tanah?

2) Bagaimana implikasi hukum terhadap penerbitan sertifikat yang tidak prosedural?

3) Bagaimanakah pertanggungjawaban pidana oleh Badan Pertanahan Nasional dalam penerbitan sertifikat hak atas tanah berdasarkan data-data palsu ?

Tujuan dari penelitian ini adalah untuk mengetahui faktor-faktor apa yang menjadi penyebab terjadinya tindak pidana pemalsuan. Untuk mengetahui implikasi hukum terhadap penerbitan sertifikat yang tidak prosedural. Dan untuk mengetahui pertanggungjawaban pidana oleh Badan Pertanahan Nasional dalam penerbitan sertifikat hak atas tanah berdasarkan data-data palsu.

\section{Metode \& Tujuan Penelitian}

Menggunakan penelitian hukum empiris, bertujuan memberikan penjelasan terhadap praktek-praktek hukum dari kebijakan pemerintah terhadap pendaftaran tanah. Di dukung jenis data yaitu data primer dan data sekunder. Data primer diperoleh dari hasil wawancara di Kantor Pertanan data sekunder terdiri dari bahan hukum primer yaitu

\footnotetext{
${ }^{7}$ Adrian Sutedi, Peralihan hak Atas Tanah, (Jakarta : Sinar Grafika, 2014) hal. 1
} 


\section{Jurnal Asy-Syukriyyah}

Undang-undang, Peraturan Pemerintah dan media elektronik, jurnal serta bahan kepustakaan lainnya dan bahan hukum sekunder menguji keabsahan empiris memberikan penjelasan terhadap praktek-praktek hukum bagaimana hukum itu dilaksanakan termasuk proses penegakan hukum pidana dan pendekatan kasus, menekankan pada alat bukti yang diambil dari peraturan undang-undang dan Peraturan Pemerintah mengenai jaminan kepastian hukum terhadap pendaftaran tanah dan penyelesaian tindak pidana pemalsuan. Serta bahan hukum tersier yaitu kamus hukum.

Tehnik pengumpulan data yang digunakan yaitu melalui studi kepustakaan dan wawancara untuk mengetahui pendapat persepsi, informasi untuk memberikan informasi sehingga dapat terwujud tujuan hukum yaitu kepastian hukum yang adil dan bermanfaat. Menggunakan teknik analisis data bersifat deskriptif kualitatif, penelitian yang bertujuan mendeskripsikan tentang kebijakan pendaftaran terciptanya kepastian hukum di bidang pertanahan dengan cara penelitian wawancara. Penelitian ini dan tujuan yang hendak di capai adalah memberikan pemahaman dan pandangan mengenai kasus-kasus pemalsuan terhadap data-data pendaftaran hak atas tanah dan hal apa yang menyebabkan suatu tindak pidana pemalsuan itu dilakukan, karena kita ketahui secara seksama masalah pemalsuan data pendaftaran hak atas tanah banyak menimpa masyarakat maupun instansi terkait, sehingga memerlukan penyelesaian yang segera agar tidak menimbulkan persoalan yang lebih besar dan memberikan hasil yang optimal bagi masyarakat maupun instansi.

\section{Kerangka Teori}

Teori berasal dari bahasa yunani yang secara etimologi yang berarti memandang, memperhatikan pertunjukan, sedangkan secara terminologi teori adalah pendapat yang dikemukakan sebagai keterangan mengenai peristiwa, kejadian yang sebenarnya, serta dapat didefinisikan sebagai pendapat, cara atau aturan untuk melakukan sesuatu. ${ }^{8}$ Teori bisa juga mengandung subjektivitas, apalagi berhadapan dengan suatu fenomena yang cukup kompleks seperti hukum ini. Berbagai aliran dalam ilmu hukum, sesuai sudut pandangan yang dipakai oleh orang-orang yang tergabung dalam aliran-aliran tersebut. ${ }^{9}$ Kerangka teori adalah kerangka pemikiran atau butir-butir pendapat, teori mengenai suatu

\footnotetext{
${ }^{8}$ Muslihin Al-Hafizah, Pengertian Teori Ilmiah, www. Referensi makalah.com/2012/08/pengertianteori-ilmiah.html diunduh pada tanggal 9 November 2014

${ }^{9}$ Satjipto Rahardjo, Ilmu Hukum, (Bandung, Citra Aditya Bakti, 2000), hal. 253
} 
kasus atau permasalahan (problem) yang menjadi bahan pertimbangan, pegangan teoritis. ${ }^{10}$ Kerangka teori merupakan landasan berpikir yang digunakan untuk mencari pemecahan suatu masalah. Setiap penelitian membutuhkan titik tolak atau landasan untuk memecahkan dan membahas masalahnya, untuk itu perlu disusun kerangka teori yang memuat pokok-pokok pikiran yang menggambarkan dari mana masalah tersebut diamati. ${ }^{11}$ Ada beberapa kegunaan kerangka teori, yaitu: ${ }^{12}$

Teori biasanya merupakan suatu ihtisar dari pada hal-hal yang telah diketahui serta diuji kebenarannya yang menyangkut objek yang diteliti, teori memberikan kemungkinan pada prediksi fakta mendatang, oleh karena telah diketahui sebab-sebab terjadinya fakta tersebut dan mungkin faktor-faktor tersebut akan timbul lagi pada masamasa mendatang, dan teori memberikan petunjuk-petunjuk terhadap kekurangankekurangan pada pengetahuan peneliti, dan teori hukum sebagai pisau analisis pembahasan tentang peristiwa atau fakta hukum yang diajukan dalam masalah penelitian. ${ }^{13}$ Teori yang digunakan dalam penelitian tesis ini adalah teori tujuan hukum sebagai teori utama (grand theory) sehingga dapat memberikan pedoman pembahasan pada uraian berikutnya. Menurut Soedjono Dirjosisworo dalam pergaulan hidup manusia, kepentingan-kepentingan manusia bisa senantiasa bertentangan satu dengan yang lain, maka tujuan hukum adalah untuk melindungi kepentingan-kepentingan itu. ${ }^{14}$ Ada beberapa pendapat sarjana ilmu hukum tentang tujuan hukum, yaitu ${ }^{15}$

1) Subekti mengatakan, bahwa hukum itu mengabdi pada tujuan negara yang dalam pokoknya ialah mendatangkan kemakmuran dan kebahagiaan pada rakyatnya.

2) L.J. van Apeldroon, mengatakan bahwa tujuan hukum ialah mengatur pergaulan hidup

manusia secara damai. Hukum menghendaki perdamaian.

\footnotetext{
${ }^{10}$ M. Solly Lubis, Filsafat Ilmu dan Penelitian, Bandung : Mandar Maju, 1994, hal. 80

${ }^{11}$ Hadari Nawawi, Metode Penelitian Bidang Sosial, (Yogyakarta, Universitas Gajah Mada Pers, 2003), hal. 39-40

${ }^{12}$ Soerjono Soekanto, Pengantar Penelitian Hukum, Universitas Indonesia, 2008, hal. 121

${ }^{13}$ Mukti Fajar Nur Dewata dan Yuliatno Achmad, Dualisme Penelitian Hukum Normatif dan Empiris, (Yogyakarta, Pustaka Pelajar, 2004), hal. 16

${ }^{14}$ Soedjono Dirjosisworo, Pengantar Ilmu Hukum, (Jakarta, Raja Grafindo Persada, 1983), hal. 11

${ }^{15}$ C.S.T.Kansil, Pengantar Ilmu Hukum Dan Tata Hukum Indonesia, (Jakarta, Balai Pustaka,
}

1986),

hal 41-45 


\section{Jurnal Asy-Syukriyyah}

Bahwa hukum mempunyai tugas untuk menjamin adanya kepastian hukum dalam masyarakat. Selain itu dapat pula disebutkan bahwa hukum menjaga dan mencegah agar setiap orang tidak menjadi hakim atas dirinya sendiri (eigenrichting is verboden), tidak mengadili dan menjatuhi hukuman terhadap setiap pelanggaran hukum terhadap dirinya. Namun tiap perkara harus diselesaikan melalui proses pengadilan, dengan perantaraan hakim berdasarkan ketentuan hukum yang berlaku, adapun 3 Tujuan Hukum yaitu :

\section{Keadilan Hukum}

Pada teorinya, Aristoteles ini sendiri mengemukakan bahwa ada 5 jenis perbuatan yang tergolong dengan adil. Lima jenis keadilan yang dikemukakan oleh Aristoteles ini adalah sebagai berikut : ${ }^{16}$

1. Keadilan Komutatif : Keadilan komutatif ini adalah suatu perlakuan kepada seseorang dengan tanpa melihat jasa-jasa yang telah diberikan

2. Keadilan Distributif : Keadilan distributif adalah suatu perlakuan terhadap seseorang yang sesuai dengan jasa-jasa yang telah diberikan.

3. Keadilan Kodrat Alam: Keadilan kodrat alam ialah memberi sesuatu sesuai dengan apa yang diberikan oleh orang lain kepada kita sendiri.

4. Keadilan Konvensional: Keadilan konvensional adalah suatu kondisi dimana jika seorang warga negara telah menaati segala peraturan perundang-undangan yang telah dikeluarkan.

5. Keadilan Perbaikan : Keadilan perbaikan adalah jika seseorang telah berusaha memulihkan nama baik seseorang yang telah tercemar.

Cita-cita keadilan yang hidup dalam hati rakyat dan yang dituju oleh pemerintah merupakan simbol dari harmonisasi yang tidak memihak antara kepentingan-kepentingan individu yang satu terhadap yang lain. ${ }^{17}$ Keadilan terpenuhi bila institusi-institusi suatu masyarakat diatur untuk mencapai keseimbangan dan kebahagiaan dengan pertimbanganpertimbangan moral dan keadilan. ${ }^{18}$ Keadilan yang dimaksud dalam kepemilikan hak atas tanah menciptakan terselenggaranya tertib administrasi yang memberi kepastian dan kemanfaatan bagi masyarakat.

\footnotetext{
${ }^{16}$ Habibulla, Teori Keadilan Menurut Aristoteles, http:-//www.-habibullahurl-.com/2015/01/teorikeadilan-menurut-aristoteles.html, diakses tanggal 5 Agustus 2018

17 R. Abdussalam, Prospek Hukum Pidana Indonesia Dalam Mewujudkan Rasa Keadilan Masyarakat, (Jakarta, Restu Agung, 2006), hal. 16

${ }^{18}$ Ibid, Hal. 17
} 


\section{Kemanfaatan Hukum}

Maksud Asas Manfaat atau Kegunaan, menurut Bentham, ialah asas yang menyuruh setiap orang untuk melakukan apa yang menghasilkan kebahagiaan atau kenikmatan terbesar yang diinginkan oleh semua orang untuk sebanyak mungkin orang atau untuk masyarakat seluruhnya. Oleh karena itu, menurut pandangan utilitarian, tujuan akhir manusia, mestilah juga merupakan ukuran moralitas. Dari sini, muncul ungkapan 'tujuan menghalalkan cara'. ${ }^{19}$ Sebagai prinsip pedoman bagi kebijakan publik, Bentham mengambil sebuah pepatah yang telah dikemukakan sejak awal abad 18 oleh seorang filsuf Skotlandia-Irlandia bernama Francis Hutcheson. Pepatahnya: "Tindakan yang terbaik adalah yang memberikan sebanyak mungkin kebahagiaan bagi sebanyak mungkin orang". Bentham mengembangkan pepatah ini menjadi sebuah filsafat moral, yang menyatakan bahwa benar salahnya suatu tindakan harus dinilai berdasarkan konsekuensi-konsekuensi yang diakibatkannya.

Konsekunsi yang baik adalah konsekuensi yang memberikan kenikmatan kepada seseorang. Di lain pihak, konsekuensi yang buruk adalah konsekuensi yang memberikan penderitaan kepada seseorang. Dengan demikian, dalam situasi apapun pedoman tindakan yang benar adalah arah memaksimumkan kenikmatan dibandingkan penderitaan. Atau dengan kata lain, meminimumkan penderitaan dibandingkan kenikmatan. Filsafat ini kemudian dikenal sebagai utilitarianisme Dinamakan demikian karena menilai setiap tindakan berdasarkan utilitasnya, yakni keberagamannya dalam membawakan konsekuensi-konsekuensi. Para pendukung filsafat ini menerapakan prinsip-prinsip tersebut dalam bidang moralitas individu, kebijakan politik, hukum, dan sosial. Filsafat ini sangat terlihat dalam memengaruhi pemerintahan Inggris. The greatest good of the greatest number yang artinya, kebaikan terbesar untuk jumlah terbesar. Prinsip ini sudah menjadi ungkapan keseharian yang sudah sangat akrab di telinga setiap orang Inggris. ${ }^{20}$ Adanya tujuan hukum yaitu kemanfaatan dalam pendaftaran tanah adalah untuk menyediakan informasi kepada pihak-pihak yang berkepentingan termasuk pemerintah agar dengan mudah dapat memperoleh data yang diperlukan dalam mengadakan perbuatan hukum mengenai bidang-bidang tanah dan satuan rumah susun yang sudah terdaftar.

\footnotetext{
${ }^{19}$ Musakhazim,Utilitiarianisme,Penjelasan,Singkat,https://--musakazhim.-wordpress.com/2007/05/07/-utilitarianisme-penjelasan singkat diakses tanggal 5 Agustus 2018

${ }^{20}$ Jeremy Bentham, http://id.wikipedia.org/wiki/Jeremy_Bentham diakses tanggal 5 Agustus 2018
} 


\section{Kepastian Hukum}

Gustav Radbruch mengemukakan 4 (empat) hal mendasar yang berhubungan dengan makna kepastian hukum, yaitu : Pertama, bahwa hukum itu positif, artinya bahwa hukum positif itu adalah perundang-undangan. Kedua, bahwa hukum itu didasarkan pada fakta, artinya didasarkan pada kenyataan. Ketiga, bahwa fakta harus dirumuskan dengan cara yang jelas sehingga menghindari kekeliruan dalam pemaknaan, di samping mudah dilaksanakan. Keempat, hukum positif tidak boleh mudah diubah. Pendapat Gustav Radbruch tersebut didasarkan pada pandangannya bahwa kepastian hukum adalah kepastian tentang hukum itu sendiri. Kepastian hukum merupakan produk dari hukum atau lebih khusus dari perundang-undangan. Berdasarkan pendapatnya tersebut, maka menurut Gustav Radbruch, hukum positif yang mengatur kepentingan-kepentingan manusia dalam masyarakat harus selalu ditaati meskipun hukum positif itu kurang adil. ${ }^{21}$ Hukum bertugas menciptakan kepastian hukum karena bertujuan untuk ketertiban masyarakat. ${ }^{22}$ Dengan adanya kepastian hukum, masyarakat akan lebih tentram, damai dan tertib. Berarti kepastian hukum menurut tepat hukumnya, subjek dan objeknya serta tepat ancaman yang diberikan. Untuk memberikan kepastian hukum dan perlindungan hukum kepada pemegang hak atas suatu bidang tanah, satuan rumah susun dan hak-hak lain yang terdaftar agar dengan mudah dapat membuktikan dirinya sebagai pemegang hak yang bersangkutan. $^{23}$

\section{Hasil Penelitian}

Faktor-faktor penyebab sehingga menimbulkan tindak pidana pemalsuan dalam pendaftaran hak atas tanah yang memberikan

1. Faktor-faktor penyebab sehingga menimbulkan tindak pidana pemalsuan data-data dalam proses pendaftaran hak atas tanah dan implikasi hukum penerbitan sertifikat yang tidak prosedural.

Dalam permasalahan yang dibahas dalam penelitian ini tentang tindak pidana pemalsuan data-data dalam proses pendaftaran hak atas tanah dapat di temukakan

\footnotetext{
${ }^{21}$ Join Community, Memahami Kepastian Dalam Hukum, http-://ngobrolinhukum.-com/2013/02/05/-memahami-kepastian-dalam-hukum/ diakses tanggal 5 Agustus 2018

${ }^{22}$ Sudikno Mertokusumo, Mengenal Hukum Suatu Pengantar, (Yogyakarta, Liberty, 1988), hal.

${ }^{23}$ Peraturan Pemerintah Nomor 24 Tahun 1997 Pasal 3
} 
faktor-faktor yang mempengaruhi sehingga menimbulkan implikasi hukum terhadap penerbitan sertifikat yang tidak prosedural yaitu :

a. Penerapan undang-undang yang tidak sesuai padahal tujuan hukum dalam pendaftaran pertanahan untuk mewujudkan kepastian hukum, diselenggarakannya pendaftaran tanah yang bersifat rechtkadaster berdasar pada Pasal 19 ayat (1) UU No. 5 tahun 1960 (UUPA) bahwa "Untuk menjamin kepastian hukum oleh Pemerintah diadakan pendaftaran tanah di seluruh wilayah Republik Indonesia menurut ketentuan-ketentuan yang diatur dengan Peraturan Pemerintah"

b. Empat syarat yang harus dipenuhi agar ketetapan dapat berlaku sebagai ketetapan sah, yaitu: I. Ketetapan harus dibuat oleh alat yang berwenang (bevoegd) membuatnya; 2. Karena ketetapan suatu pemyataan kehendak (wilsverklaring), maka pembentukan kehendak itu tidak boleh memuat kekurangan yuridis (geenjuridische gebreken in de wilsvorming); 3. Ketetapan harus diberi bentuk (vorm) yang ditetapkan dalam peraturan yang menjadi dasannya dan pembuatnya harus juga memperhatikan cara (procedure) membuat ketetapan itu bilamana cara itu ditetapkan dengan tegas dalam peraturan dasar tersebut; 4. dan terakhir lsi dan tujuan ketetapan harns sesuai dengan isi dan tujuan peraturan dasar. ${ }^{24}$ Apabila salah satu syarat tidak dipenuhi, maka ketetapan yang bersangkutan menjadi ketetapan yang tidak sah, misalnya: Ketetapan yang dibuat oleh orang atau pejabat yang tidak berwenang (on bevogd), ketetapan itu dibuat karena adanya penipuan (bedrag), ketetapan itu tidak menurnt prosedur berdasarkan hukum (rechtmatige) dan ketetapan itu tidak memenuhi tujuan peraturan dasannya (doelmatige) atau telah teIjadi penyalahgunaan wewenang (detounament depauvoir).

c. Prosedur yang salah maupun satu syarat tidak dipenuhi, maka ketetapan yang bersangkutan menjadi ketetapan yang tidak sah, misalnya: Ketetapan yang dibuat oleh orang atau pejabat yang tidak berwenang (on bevogd), ketetapan itu dibuat karena adanya penipuan (bedrag), ketetapan itu tidak menurnt prosedur berdasarkan hukum (rechtmatige) dan ketetapan itu tidak memenuhi tujuan peraturan dasannya (doelmatige) atau telah teljadi penyalahgunaan wewenang (detounament depauvoir).

${ }^{24}$ Utrecht, Pengantar Administrasi Negara Indonesia, (Jakarta:Balai Buku Ikhtiar, Tahun 1963) h 104-105. 
d. Perbuatan hukum Pemerintah/BPN dalam melakukan pendaftaran tanah dan menerbitkan sertifikat sebagai suatu perbuatan hukum, untuk menimbulkan keadaan hukum baru dan melahirkan hak-hak serta kewajiban-kewajiban hukum baru terhadap orang/subyek hukum tertentu, harus memenuhi syarat-syarat dan tidak boleh mengandung unsur kesalahan baik menyangkut aspek teknis pendaftaran tanah maupun aspek yuridis. Kesalahan dalam hal ini berakibat batal atau dapat dibatalkan bahkan jika ada unsur-unsur pidana seperti pemalsuan akan memberikan implikasi hukum terhadap penerbitan sertifikat.

e. Kesalahan data fisik maupun data yuridis dalam pendaftaran tanah akan menghilangkan unsur kepastian hukum hak atas tanah, sehingga orang yang berhak terhadap tanah tersebut akan dirugikan. Kesalahan juga akan berakibat terjadinya informasi yang salah di BPN sebagai alat kelengkapan negara yang akibatnya juga berarti menciptakan administrasi pertanahan yang tidak tertib.

2. Kesalahan Badan Pertanahan Nasional (BPN) yang dilakukan oleh oknum petugasnya adalah seringkali terjadi akibat kurang teliti dalam proses verifikasi berkas dan datadata pemohon, bahkan juga terjadi konspirasi antara pihak pemohon pendaftaran tanah dengan petugas pertanahan yang mengakibatkan terbitnya sertifikat yang bermasalah.

3. Pemahaman hukum masyarakat yang masih rendah mengakibatkan kesalahankesalahan yang dilakukan oleh oknum petugas pertanahan menjadi sesuatu yang permisif oleh masyarakat kita.

4. Dalam Undang-Undang Pokok Agraria (UUPA) pengaturan terkait sanksi pidana sangat minim sehingga kesalahaan-kesalahan dan perbuatan melawan hukum yang disengaja menjadi justifikasi untuk mendapatkan keuntungan dari proses pendaftaran hak atas tanah dan diterbitkannya sertifikat hak atas tanah.

Pertanggungjawaban pidana oleh BPN dalam penerbitan sertifikat dengan dasar data-data palsu dan implikasi hukumnya terhadap sertifikat yang diterbitkan. Suatu tindak pidana harus memenuhi unsur-unsur objektif, yaitu ada suatu perbuatan yang dirumuskan secara positif dalam KUHP (asas legalitas) yang telah dilakukan oleh seseorang itu harus memenuhi unsur-unsur subyektif, yaitu orang yang melakukan perbuatan tersebut harus dapat bertanggung jawab dalam artian orang tersebut tidak sakit atau berubah akal/gila, tidak dalam keadaan terpaksa dan dalam keadaan darurat. 


\section{Jurnal Asy-Syukriyyah}

Dalam penerapan hukum pidana, menurut pendapat ahli hukum mengatakan bahwa unsur-unsur melawan hukum adalah unsur suatu delik, maka unsur melawan hukum itu tetap dianggap ada secara diam-diam, meskipun unsur melawan hukum itu tidak dirumuskan secara tegas dalam rumusan suatu delik. Ajaran melawan hukum materil tersebut adalah sudah merupakan satu keharusan dalam penerapan hukum pidana modem. Ajaran ini telah melunakkan kekuatan dari Pasal 1 ayat (I) KUHP yang sudah tidak dapat kita pertahankan lagi secara konsekuen dalam era dewasa ini.

Asas ini dapat ditafsirkan berlaku dalam hukum pertanahan, meskipun sanksi pidana tidak diatur secara khusus dalam peraturan perundang-undangan pertanahan, tidak berarti pihak Kepolisian tidak dapat melakukan penyidikan terhadap pelanggaran dan kejahatan dalam bidang hukum pertanahan. Sesuai dengan paparan di atas, kebijakan dekriminalisasi yang terdapat dalam PP No. 24 Tahun 1997 tidak menutup kemungkinan bagi penyidik Polri untuk melakukan penyidikan terhadap pelanggaran dan kejahatan di bidang pertanahan. Penyidik Polri masih dapat mempergunakan hukum Pidana Umum (KUHP) sebagai dasar penyidikannya. ${ }^{25}$

Para petugas BPN sebagai instansi yang berwenang, dalarn hal penerbitan sertifikat hak-hak atas tanah, perlu terlebih dahulu rnerneriksa rekaman data fisik dan data yuridis dalam buku tanah, supaya penerbitan sertifikat tidak tumpang tindih atau terdapat dua (2) sertifikat atau lebih di atas satu (I) bidang tanah. Kernungkinan juga bisa teljadi di atas sertifikat Hak Milik dikeluarkan pula Hak Guna Usaha (HGU). Apabila ada pihak yang rnerasa dirugikan dan mengadukan masalahnya ke pihak kepolisian, maka pihak Polri harus melakukan investigasi tentang proses, prosedur, dan jika perlu atas kewenangannya dapat melihat buku tanah yang bersangkutan, berdasarkan Pasal 131 dan Pasal 132 KUHAP. $^{26}$

Dalam rangka penyidikan kasus pemalsuan, pihak polri dapat mempergunakan hukum pidana umum sebagaiman yang telah dipaparkan di atas. Pembuktian yang menyangkut peristiwa pidana tersebut dapat dilakukan sesuai dengan Pasal $164 \mathrm{HIR} / \mathrm{Pasal}$ 184 KUHAP yang dimulai dari bukti tulisan, kesaksian, persangkaan, pengakuan dan sumpah yang dapat diambil dari dokumen para saksi maupun tersangka dalam kasus

\footnotetext{
${ }^{25}$ Peraturan Pemerintah No.24 Tahun 1997

${ }^{26}$ Semua penge!uaran untuk penye!esaian hal lersebul dalam pasal ini dibebankan sebagai biaya
} perkara. 


\section{Jurnal Asy-Syukriyyah}

tersebut. Diantara bukti tersebut yang paling dominan diperhatikan adalah bukti tertulis baik dalam akta autentik maupun dalam bukti tulisan lainnya.

Berdasarkan pembahasan diatas bahwa Peraturan Perundang-undangan yang mengatur tentang penerbitan sertifikat hak milik oleh BPN telah banyak terdapat pelanggaran-pelanggaran yang dilakukan oleh oknum pemerintahan yang berkaitan dengan penerbitan sertifikat hak atas tanah. Sehingga perlu dilakukan perubahan aturan-aturan yang mengatur tentang sistem pendafatran tanah dan melakukan perbaikan terhadap sanksi pidana bagi oknum pejabat yang terlibat dalam penerbitan sertifikat khususnya instansi yang berwenang terhadap penerbitan izin tersebut.

Dalam hal pendaftaran tanah yang di perintahkan oleh undang-undang yaitu badan pertanahan nasional sesuai tugas dan fungsi Badan Pertanahan Nasional berdasarkan undang-undang No 10 Tahun 2006 yaitu badan pertanahan nasional bertugas menjalankan tugas pemerintah dibidang pertanahan secara sectoral, regional, dan nasional dan menyelesaikan konflik pertanahan. Berarti BPN yaitu pejabat yang bertanggungj jawab menerbitkan sertifikat dapat dimintai pertanggungjawaban pidana dengan sanksi pidana yang diatur dalam UUPA.

Berdasarkan sanksi pidana yang diatur dalam Undang-undang pokok agraria No. 5 tahun 1960 Pasal 52 yang menjelaskan bahwa berdasarkan peraturan perundangundangan yang melanggar pasal 19, 22, 24, 26 dan 46, 47, 48, 49 ayat (3) dan 50 ayat (2) dapat memberikan ancaman pidana atas pelanggaran peraturannya dengan hukuman kurungan selama-lamanya 3 bulan dan/atau denda setinggi-tingginya Rp. 10.000. Melihat denda dan kurungan, sepertinya terlalu sederhana dengan kerugian yang dialami oleh masyarakat karena adanya malpraktik.

\section{Penutup}

Sesuai dengan paparan di atas maka kebijakan kriminalisasi terhadap kasus tindak pidana dalarn hukum pertanahan adalah sesuai dengan ajaran hukum pidana yang menganut asas melawan hukum materiil, dalam arti bahwa perbuatan pidana tidak hanya merupakan perbuatan yang bertentangan dengan undang-undang tertulis saja, tetapi termasuk juga perbuatan yang bertentangan dengan hukum tidak tertulis. Alasan pengecualian hukuman dari perbuatan tersebut, harus dicari juga berdasarkan hukum tertulis dan hukum tidak tertulis. Dengan berlakunya ajaran melawan hukum materiil maka 
ketentuan Pasal I ayat (I) KUHP telah berlaku negatif, yaitu asas legalitas yang menentukan bahwa seseorang tidak dapat dihukum kecuali undang-undang mengaturnya terlebih dahulu, ketentuan ini telah tereliminasi dengan berlakunya asas melawan hukum materi!.

Sifat melawan hukum dari satu perbuatan dianggap ada secara diam-diam meskipun tidak dengan tegas dirumuskan dalam delik pidana. Untuk membuktikan adanya sikap melawan hukum, dapat dipakai asas perbuatan melawan hukum on recht matigedaad yang berlaku dalam Pasal 1365 KUH Perdata, yaitu perbuatan melawan hukum dapat ditafsirkan sebagai membuat sesuatu atau melalaikan sesuatu yang (a) melanggar hak orang lain, (b) bertentangan dengan kewajiban hukum (rechtsplicht) dari yang melakukan perbuatan itu, (c) bertentangan dengan baik kesusilaan maupun asas-asas pergaulan kemasyarakatan mengenai penghormatan diri orang lain atau barang orang lain. Meskipun kebijakan kriminalisasi tidak ada dalam perundang-undangan pertanahan, khususnya dalam pendaftaran tanah, namun terhadap kejahatan dan pelanggaran dalam pendaftaran dan penerbitan sertifikat tanah, pihak Polri dapat melakukan penyidikan dengan KUHP atau pidana umum. 


\section{DAFTAR PUSTAKA}

Supriadi. 2010. Hukum Agraria. Cetakan keempat.

Jimly Asshiddiqie Gagasan Negara Hukum Indonesia. Konsep Negara Hukum. Dalam www.jimly.com/makalah/namafile/135/Konsep_Negara_Hukum_Indonesia.pdf

Amiruddin Salle. 2007. Hukum Pengadaan Tanah Untuk Kepentingan Umum. Cetakan Pertama, Yogyakarta : Kreasi Total Media (KTM).

Mudjiono, Politik dan Hukum Agraria, Cet. Pertama, Liberty, Yogyakarta,1997

Chandra. S, Sertifikat Kepemilikan Hak Atas Tanah, Jakarta: Raja Grafindo Persada, 2005. Sutedi Ardian, Peralihan hak Atas Tanah, Jakarta : Sinar Grafika, 2014.

Muslihin Al-Hafizah, Pengertian Teori Ilmiah, www. Referensi makalah.com/2012/08/pengertian-teori-ilmiah.html diunduh pada tanggal 9 November 2014

Rahardjo Satjipto, Ilmu Hukum, Bandung, Citra Aditya Bakti, 2000.

Lubis Solly, Filsafat Ilmu dan Penelitian, Bandung : Mandar Maju, 1994.

Soerjono Soekanto, Pengantar Penelitian Hukum, Universitas Indonesia, 2008, hal. 121

Mukti Fajar Nur Dewata dan Yuliatno Achmad, Dualisme Penelitian Hukum Normatif dan Empiris, (Yogyakarta, Pustaka Pelajar, 2004), hal. 16

Soedjono Dirjosisworo, Pengantar Ilmu Hukum, (Jakarta, Raja Grafindo Persada, 1983), hal. 11

C.S.T.Kansil, Pengantar Ilmu Hukum Dan Tata Hukum Indonesia, (Jakarta, Balai Pustaka, 1986), hal 41-45

Habibulla, Teori Keadilan Menurut Aristoteles, http:-//www.-habibullahurl.com/2015/01/teori-keadilan-menurut-aristoteles.html, diakses tanggal 5 Agustus 2018

R. Abdussalam, Prospek Hukum Pidana Indonesia Dalam Mewujudkan Rasa Keadilan Masyarakat, (Jakarta, Restu Agung, 2006), hal. 16 Ibid, Hal. 17 


\section{Jurnal Asy-Syukriyyah}

Musakhazim,Utilitiarianisme,Penjelasan,Singkat,https://--musakazhim.-wordpress.com/2007/05/07/-utilitarianisme-penjelasan singkat diakses tanggal 5 Agustus 2018

Jeremy Bentham, http://id.wikipedia.org/wiki/Jeremy_Bentham diakses tanggal 5 Agustus 2018

Join Community, Memahami Kepastian Dalam Hukum, http-://ngobrolinhukum.-com/2013/02/05/-memahami-kepastian-dalam-hukum/ diakses tanggal 5 Agustus 2018

Sudikno Mertokusumo, Mengenal Hukum Suatu Pengantar, (Yogyakarta, Liberty, 1988), hal. 58

Peraturan Pemerintah Nomor 24 Tahun 1997 Pasal 3

Utrecht, Pengantar Administrasi Negara Indonesia, (Jakarta:Balai Buku Ikhtiar, Tahun 1963) h 104-105. 